\title{
The EU ETS Top Ten Polluters List as a Policy Tool of Climate Action Organisations
}

\author{
By Andrei Zimakov ${ }^{1}$
}

\begin{abstract}
The EU ETS is one of the most important EC instruments to curb $\mathrm{CO}_{2}$ emissions. Various climate action organisations use verified emissions data from EU ETS to calculate top EU polluters lists. These shortlists are actively used in their advocacy strategies as an evidence of national or EU-wide climate policies (under)performance to influence policymaking. However, there is no official EU ETS top ten list released by the EC what weakens the political power of this tool. Addressing possible reasons for EC's reluctance the paper investigates the correlation between the presence of national enterprises in the EU ETS top ten list and the national climate policy actions over 2008-2019 timeframe. Despite different limitations, the EU ETS top ten is adequately reflecting main developments in national efforts to curb GHG emissions and is pointing out underperforming countries and industries covered by the EU ETS. In the variety of hard and soft EU climate policy instruments, the EU ETS top ten polluters list could feature as an information tool. It is especially important for climate action organizations, providing them with an officially released rating as a common reference point that they could use in their evaluations and political campaigns.
\end{abstract}

Keywords: top polluters list; climate policy; EU emissions trading system; energy transition; coal phase-out; climate action organisations

\section{Introduction}

The European Union (EU) is one of the world's leaders in combating climate change. Through the adoption of EU-wide policies to decarbonize the economy, it envisages to become climate neutral by 2050. To achieve this, the European Commission (EC) has introduced binding directives with interim $(2020,2030)$ climate targets for its member countries. Along with higher share of renewables and better energy efficiency, the major goal remains the reduction in greenhouse gas (GHG) emissions that should ultimately contribute to the global warming limit of $2{ }^{\circ} \mathrm{C}$ or even $1.5^{\circ} \mathrm{C}$ (above the preindustrial level) targeted by the Paris Agreement. To curb CO2 emissions, the EU has developed several instruments, EU Emissions Trading System (EU ETS) being the most important of them (Verbruggen et al. 2019). The EU ETS covers most energy-intensive industries like power and heating production, metal ores, pulp and paper processing, mineral processing as well as aviation sector that are jointly responsible for around 39\% of the EU's GHG emissions (European Commission 2020).

As a 'cap and trade' system, the EU ETS is collecting annual data on GHG verified emissions from the installations to be able to control they are balanced by allowances. Apart from its main function, the GHG emissions data from EU ETS is used by different 
actors like climate action organizations or think tanks to calculate an EU top polluters list. Based on 'dirty' companies listed, the climate NGOs make their evaluation of performance for national or EU-wide climate policies, which is then used in their publicity campaigns. Being a quite straightforward and obviously limited approach, the EU ETS top polluters lists released by climate action organisations, nevertheless, attract enough attention and coverage in the mass media, thus indirectly influencing policymaking. However, there is no official EU ETS top ten list as the European Commission (EC) does not calculate and release the EU ETS top ten. This generally explains the existence of several top ten lists calculated by NGOs applying different methodological approaches.

Possible reason for this might be the EC is not considering the EU ETS top ten to be a valid climate policy performance indicator for their own use. As a short list of most polluting installations, it is obviously less informative than far more extensive indicators like total $\mathrm{CO}_{2}$ emissions (including both EU ETS and EU Effort Sharing) by industry or by country. The EU ETS top ten has clearly no value for the EC in evaluation of national climate policy efforts. Nevertheless, the EU ETS top ten is firm in the toolkit of climate action organisations that are an important ally of the EC in promoting clean energy transition (Derman 2014). Civil society organisations and public opinion are significant driving forces of climate policy beyond the member states and EU institutions (Bernauer 2013).

As a shortlist, the EU ETS top ten benefits from the effects related to heuristics in decision-making process (Ramsey 2020). Shortlisting procedure as a behavioural model is thoroughly investigated in both psychology and economy. The information processing theory (Miller 1955) suggests that shortlists help us to overcome limitations of our capacity to process information. Ranking and ordering is essential part of the rational choice theory (Arrow 1959; Simon 1956). Later economic research supports the importance of shortlisting procedure for rational decision-making to overcome the "choice overload" (Manzini \& Mariotti 2007; Dutta \& Horan 2015; Lleras et al. 2017; Ramsey 2019; Geng \& Özbay 2020, Qin 2021).

Building on those effects, the EU ETS shortlist is more straightforward and addressed compared to discrete complex aggregated $\mathrm{CO}_{2}$ emissions indicators. The shortlist with most 'dirty' installation is easier to perceive for a non-professional. In addition to that, it helps the publicity to establish a cognitive link between overall national pollution figures and particular enterprises or industries, because the installations are more visible and tangible, than abstract indicators. This aspect plays an important role in NGOs' advocacy strategies as it involves emotional response (Jasper 2011; Salgado 2018).

However, the absence of the official EU ETS top ten list weakens the political power of this tool as it may be challenged for different methodological approaches or bias. Without endorsement by the EC, it remains a kind of unofficial 'by-product' of the EU ETS.

Recent research on EU climate policy suggests, that it is too focused on EU ETS as almost sole instrument to curb GHG emissions and that there is a need in a mix of measures that promote both low-carbon innovation and the decline of carbon-intensive industries (Markard \& Rosenbloom 2020). Along with the variety of hard and soft EU climate policy instruments, there is also option for smaller tools like the introduction of rating systems. Rankings and rating systems are already part of the EU climate policy toolbox, although it is primarily applied as a consumption-oriented instrument (Grubb et al. 2020). The release 
of an EU ETS top ten would be especially important for climate action organizations, because the official status of the EU ETS top ten could boost the political power of this tool and provide different actors with a common reference point.

Moreover, there have been several studies exploring political power of relative performance indicators recently (Davies et al. 2020; Doshi et al. 2019; Olsen 2015). Therefore interpreted as an indicator of a relative climate policy performance the EU ETS top polluters list can potentially have even more influence on national or EU-wide policymaking as an instrument to accelerate the ongoing low-carbon energy transition.

Another possible reason for the EC to not make adequate use of this tool might be the uncertainty whether the top ten list approach is accurate in assessing tendencies in national climate policies performance. The objective of this paper is to determine whether the EU ETS top ten list is adequately reflecting (under)performance of national climate policies, to identify the limitations of the EU ETS top ten list and to analyse its ability to be instrumental in promoting clean energy transition in the EU.

\section{Methodology}

\subsection{Data sources}

The input data is taken from EU ETS Union Registry reports 2008-2019, that contain annual verified $\mathrm{CO}_{2}$ emissions data received from operators of installations as required by Directive 2003/87/EC (with further amendments) and corresponding guidelines. The reports can be found at the site of the European Commission in the section dedicated to the Union Registry. The data for preceding year is submitted by operators before March 31 st and usually released by the European Commission in early April, but due to the nature of emission data capturing later adjustments can impact the results. For example, verified emissions data for 2015 published on 1st April 2016 had zero for the biggest European power plant Bełchatów, because no data had been provided by the operator in due time. The correct 2015 emissions figure for Bełchatów was later updated in 2017. Therefore, all data is checked against later Union Register reports releases except for 2019. The results of EU ETS top ten calculations for 2019 should be considered preliminary.

Normally each facility has only one operator account in the EU ETS for reporting verified emissions and receive allocations. Nevertheless, due to the fact the EU ETS reporting is installation-based, there are several exceptions, Boxberg power station being the biggest among them and therefore most important for this study. Boxberg power station initially consisted of four separate plants, with the older two shut down in 2000. Each of the remaining plants III and IV has its own account in the EU ETS, with emissions data filed and allocations managed separately. Same applies for Torrevaldaliga power station with separate accounts for plants Nord and Sud. This split may be important for environmental considerations but is irrelevant for the purposes of this study and therefore neglected.

It should be noted, that during 2008-2019 the EU ETS has evolved expanding its coverage of the industries. Currently the EU ETS is transitioning from Phase III (2013-2020) to Phase IV (2021-2030). The main difference in the switch from the previous Phase II (20082012) to Phase III in terms of this study lies in the coverage of the industries. Phase III added to ETS the production of all metals and the aviation industry, covering all flights 
within the EEA. This fact was taken into account when comparing verified emissions ranking for 2008-2012 and 2013-2019 periods, because the inclusion of a new industry into EU ETS may affect the composition of the top ten list.

\subsection{Methods}

The study is based on qualitative and comparative analysis of the top ten polluting European installations for a timeframe 2008-2019. A two-phase research process was used to evaluate the correlation between the presence of national enterprises in the EU ETS top ten list and the national climate policy actions.

In the first phase, to calculate a top ten list for a given year EU ETS annual verified emissions data for that year are arranged in descending order with a cut-off after tenth line. The derived list of ten top polluters is further analysed based on company's industry attribution and spatial allocation. The outcome of the first phase is a set of EU ETS top ten lists for a timespan 2008-2019, that provides basis for further analysis.

In the second phase, year on year changes in EU ETS top ten lists composition and ranking are analysed to determine any trends for installations from the same countries. These trends are then evaluated against relevant national climate policy performance in curbing GHG emissions with the purpose to establish whether there is correlation in the national climate policy efforts and changes in the ranking of respective national installations present in the EU ETS top ten.

The basic hypothesis is that in an absence of significant national climate action political shifts the presence of national enterprises in the top ten list will be close to constant over time or can show an upward trend with more installations joining the list. At the opposite enacting of national environmental policies will entail respective changes in the ranking with downward trend.

It is expected that the ranking of ETS top ten polluters will be less sensitive to market volatility within one industry since market forces will be affecting the production of all installations of the same industry in more or less similar way. Nevertheless, cross-industry shifts driven by market fluctuations are potentially possible. (In this respect, it would be interesting to assess the impact of COVID-19 driven restrictions on the EU ETS top ten when the data is available.)

\section{Results}

The calculated EU ETS top ten lists for 2008-2019 are presented in Appendix A. The results show, that the core of the EU ETS top ten polluters list remains stable over 2009-2019 period. Number one is unchanged for the whole period (Bełchatów power station in Poland). Since 2015 it is joined by Kozienice power plant what brings the share of Poland installations in the top ten to $20 \%$. German lignite-firing power stations take a $50-60 \%$ share in the list in 2009-2015, rising to $70 \%$ since 2016 .

The variation in the top ten is in the range of $40-30 \%$ share. UK's installations share has dropped from maximum of 20\% in 2013 to zero since 2016. Greece's Agios Dimitrios power plant has left the list in 2015. Over the time, the list was for several years temporarily joined by one Italian hard-coal power station and one Bulgarian lignite power plant. If in 2009-2015 the top ten included installations from five EU counties; since 2016, the 
composition is $70 \%$ Germany, 20\% Poland with the third country changing.

Industry-wise thermal power stations burning hard coal or lignite as a fuel dominate the list. In 2012 France's ArcelorMittal Atlantique et Lorraine - Dunkerque steel plant made it to number ten, but only once. Since 2018, aviation company Ryanair DAC joined the top ten list taking line 8 representing an upward trend.

Downward and stable trends are also present in the EU ETS top ten lists based on year on year analysis. Installations for Poland and Germany maintain their positions in the rating for the whole period, while installations from the UK, Greece and Italy leave the list over the time. The trends observed in the EU ETS top ten correlate with trends in respective national EU ETS $\mathrm{CO}_{2}$ emissions levels.

\subsection{Downward trend in coal phase out countries}

Coal firing power stations taking almost the entire top ten list is explained by the fact that burning coal and lignite is one of the environmentally dirtiest technologies (Gasparotto \& Martinello 2020). Thermal power plants (TPP) burning hard coal and especially lignite emit significantly more $\mathrm{CO}_{2}$ and other harmful substances than for example natural gas (Dickel 2018). From climate policy standpoint the existence of coal power plants is considered incompatible with achieving GHG emissions reduction target, because the expansion of renewables in power generation can't deliver to reduction of GHG alone, but only through substitution of carbon-emitting technologies with low- or non-carbon ones (Zhao \& You 2020). Therefore, a Europe-wide coal phase out in power generation has gradually become one of major issues in climate action agenda (Rentier et al. 2019). However, at a national level the political perception of coal phase out was quite different among the EU members. While several EU countries have quite early embraced climate policies stimulating or even forcing coal out of power generation, other EU members, especially those producing hard coal and lignite, have struggled to adopt a phaseout strategy (Zimakov 2017). The EU ETS top polluters list is generally reflecting this development. The installations from those countries pursuing a phase out policy have successively left the list giving way to power plants from lagging countries.

The UK represents a successful case in bringing the share of coal in power generation down from $32 \%$ in 2008 to $2.1 \%$ in 2019 as a result of a climate policy efforts and is going to phase out coal completely by 2025 or even earlier. The introduction of carbon tax and pollution limiting legislation has made coal power generation uneconomical, what has led to a series of coal power stations closures in the UK in the last five years (Isoaho \& Markard 2020). As part of this development Eggborough power plant, that occupied line 10 of EU ETS in 2013, was closed down in 2018 after three years of unstable operation at low capacity. An alternative option for coal-firing power plants is to switch to biomass (CCC 2018). The biggest UK's coal power station Drax with six units of 3.9 GW installed capacity used to be number four in the EU ETS top ten until 2012, when it started to descend: initially to line five and then to line six in 2014. In 2016 Drax power station has left the top ten list (Figure 1). The reason for that is the conversion of its four units to burning biomass in 2014-2018 as a decarbonisation measure, which has brought the emissions down from 22.7 million t $\mathrm{CO}_{2}$ in 2012 to below 1 million t $\mathrm{CO}_{2}$ in 2019 (Figure 2). 
Figure 1. Drax power station ranking in the EU ETS top ten.

\begin{tabular}{|c|ccccccccc|}
\hline Rank & 2008 & 2009 & 2010 & 2011 & 2012 & 2013 & 2014 & 2015 & 2016 \\
\hline 4 & Drax & Drax & Drax & Drax & & & & & \\
\hline 5 & & & & & Drax & Drax & & \\
\hline 6 & & & & & & & Drax & Drax \\
\hline
\end{tabular}

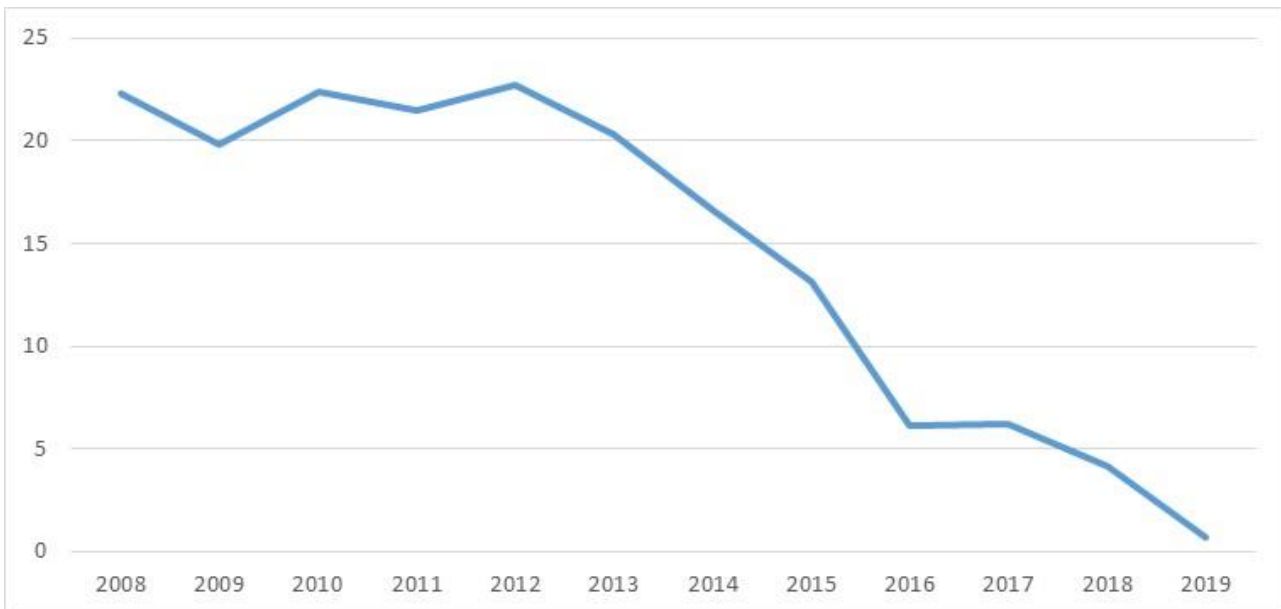

Figure 2. Drax power station verified emissions 2008-2019, $m \ln +\mathrm{CO}_{2}$.

Agios Dimitrios lignite power station (Greece) was in the EU ETS top ten list in 20092014, but has left it in 2015 (Figure 3) what was associated with a decrease in emissions from 14,3 million t $\mathrm{CO}_{2}$ in 2010 to below 10 million t $\mathrm{CO}_{2}$ since 2016 (Figure 4). In line with Greece's commitment to phase out lignite in power generation (by 2028) the first four units of Agios Dimitrios power station will be shut down in 2022 and the last unit in 2023 (NECP 2019: 96). Although it's hard to establish a direct link with the reduction of Agios Dimitrios power plant's emissions and Greece climate policy efforts, it should be nevertheless noted, that the share of lignite in power generation in Greece has dropped from $56 \%$ in 2014 to $25,4 \%$ (EnEx 2020) as a result of climate policy-driven measures (Vlassopoulos 2020). While the installed capacity of lignite power plants in Greece remained practically unchanged since 2016 with $3.9 \mathrm{GW}$, they are increasingly used to tackle peak demands or partly ensuring base load giving way to less environmentally harmful natural gas power generation.

Figure 3. TPP Agios Dimitrios ranking in EU ETS top ten.

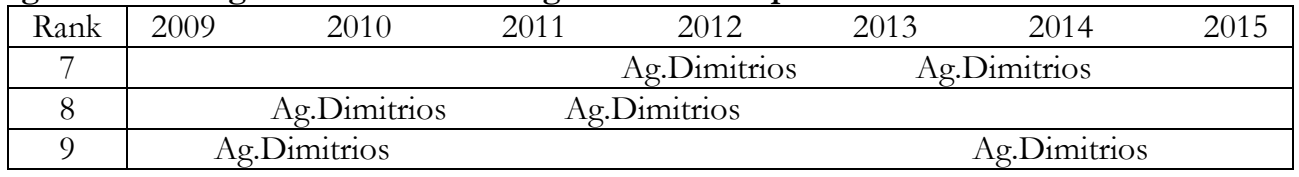




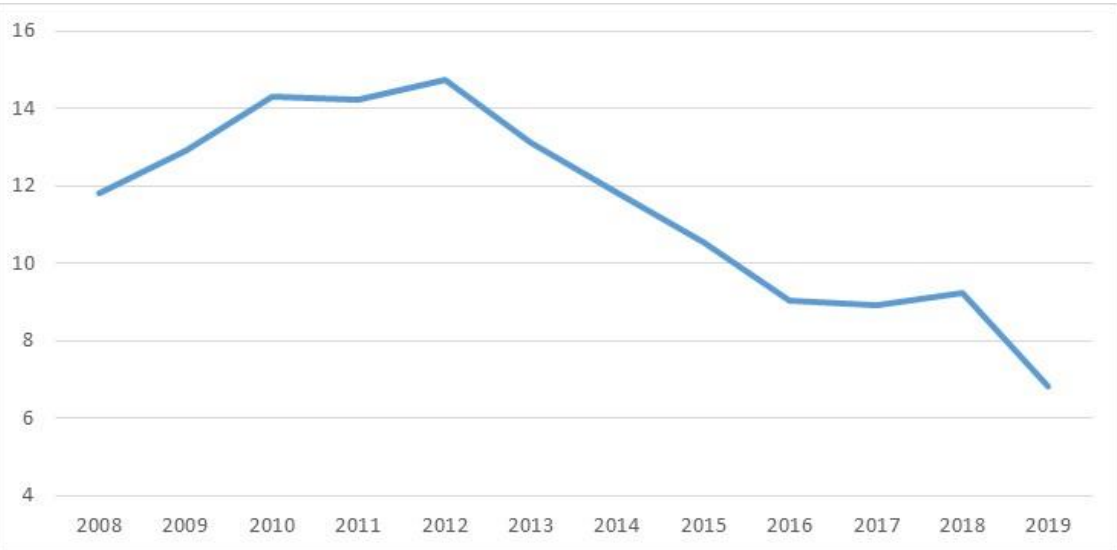

Figure 4. TPP Agios Dimitrios verified emissions 2008-2019, mln $t \mathrm{CO}_{2}$.

Similar approach to management of coal power generation can be witnessed in Italy, where the actual coal power generation has been increasingly reduced since 2016 while the installed capacity remained the same at $8,3 \mathrm{GW}$. Currently the coal-fired generation is mainly used in peak demand periods what helps to reduce total emissions of the power sector (Fermeglia 2020). Italy has set a target to phase out coal power plants by 2025. For some of the plants the closure will happen even earlier. Enel is planning to shut down unit 2 at Brindisi Sud in early 2021 along with two other coal power stations (Enel 2020). These trends in Italian power sector can be traced in the EU ETS top ten list, where two Italian power stations Torrevaldaliga Nord and Brindisi Sud can be found in 2009-2016, but none of them since 2017.

\subsection{Stable trend in coal-dependent power generation countries}

Until recent indications of a coal phase out by 2049, Poland has been among EU states reluctant to commit to 2050 climate neutrality target (Euractiv 2020). Poland's power generation is heavily dependent on coal that makes over $80 \%$ of national electricity production. This explains the fact Poland power plants retained and increased their share in the top ten list over time. Bełchatów power station remains a long-standing number one in the EU top ten for the whole period (Figure 5) what is partly explained by its size - the biggest power plant in the EU and the biggest lignite-firing power station in the world. However, over the observed timeframe the verified emissions of Bełchatów TPP remained relatively stable. In the recent years, the power station became a target for climate action organizations, one of them even starting a legal challenge for its harm to the environment (The Guardian 2019).

Figure 5. Poland's power stations ranking in EU ETS top ten

\begin{tabular}{|c|c|c|c|c|c|c|c|}
\hline Rank & $2009-$ & -2014 & 2015 & 2016 & 2017 & 2018 & 2019 \\
\hline 1 & Bełchatów & Bełchatów & Bełchatów & Bełchatów & Bełchatów & Bełchatów & Bełchatów \\
\hline$\ldots$ & & & & & & & \\
\hline 7 & \multicolumn{7}{|c|}{ Kozienice } \\
\hline 8 & & & & & Kozi & enice & Kozienice \\
\hline 9 & \multicolumn{7}{|c|}{ Kozienice } \\
\hline 10 & \multicolumn{7}{|c|}{ Kozienice } \\
\hline
\end{tabular}




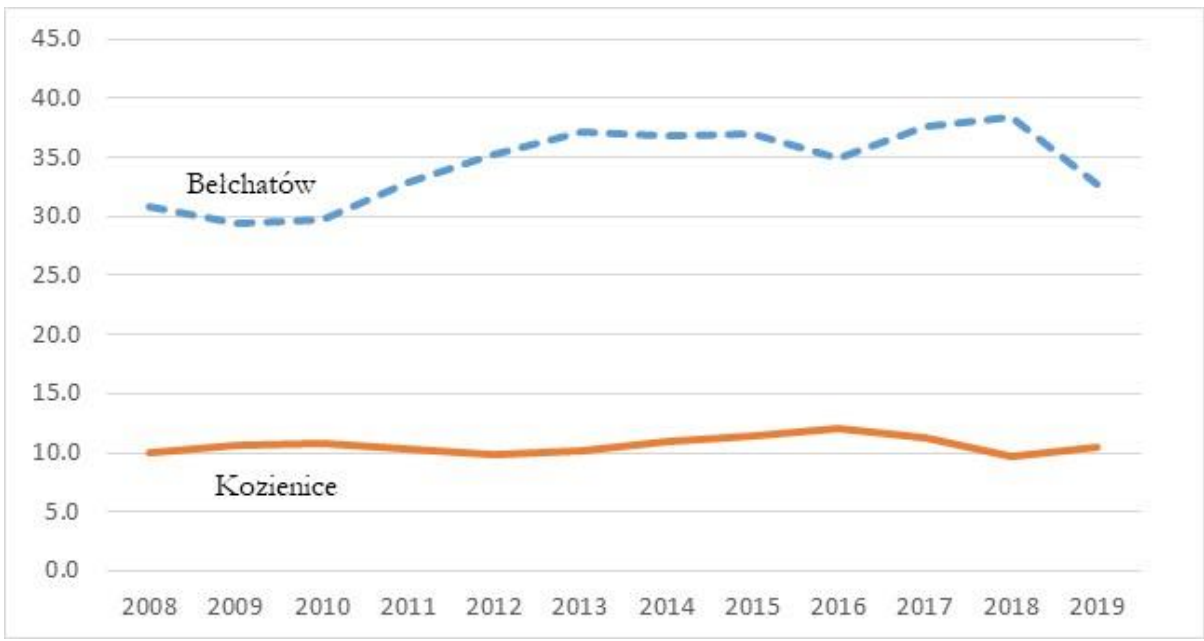

Figure 6. Poland's power stations verified emissions 2008-2019, $m \ln +\mathrm{CO}_{2}$.

The second power plant from Poland, that has joined the EU ETS top ten since 2015, shows little change in verified emissions over the observed timeframe (Figure 6). The reason for TPP Kozienice to ascend to top ten is actually the reduction in verified emissions of thermal power plants in other countries, so that they have left the top ten list giving way for installations that have not reduced the emissions. Figure 7 shows cumulative verified emissions of the power plants in EU ETS (activity code 20) from Poland, Germany and the rest of EU.

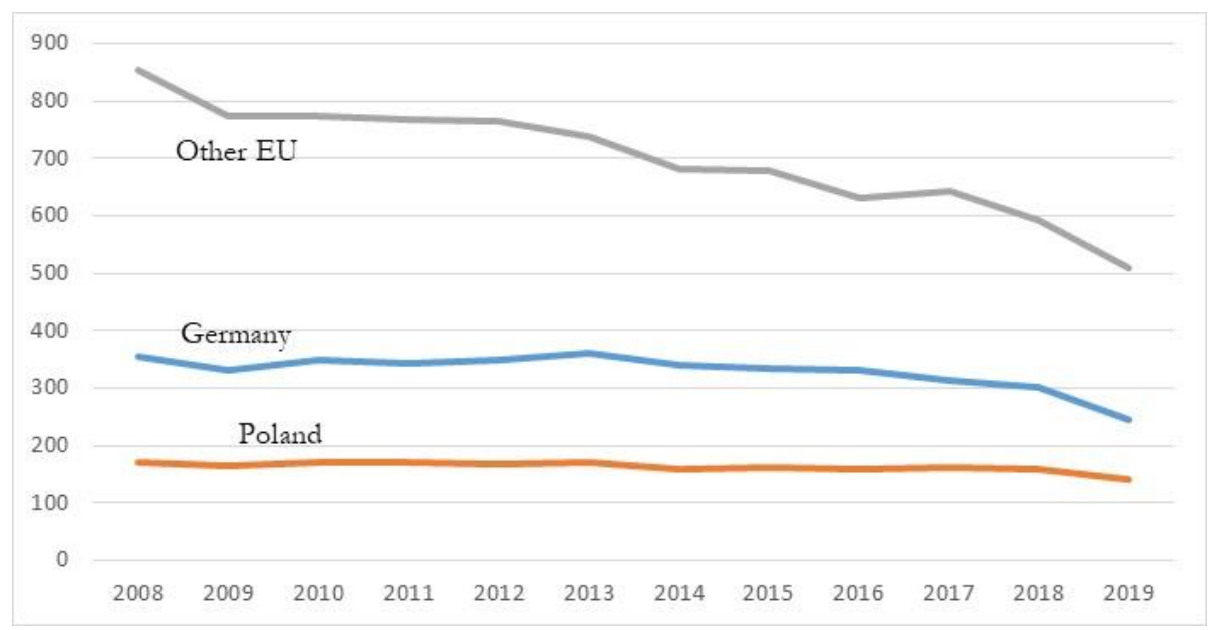

Figure 7. Verified emissions of thermal power plants in Poland, Germany and the rest of EU 2008-2019, mln $t$ $\mathrm{CO}_{2}$.

Germany's lignite-firing power stations with minor variations build up the core of the EU ETS top ten polluters list for the whole observed period with a 50-60\% share in 20082015, rising to $70 \%$ since 2016. TPP Niederaußem, Neurath, Jänschwalde, Weisweiler are 
firm in the top ten lists 2008-2019 mainly in the upper part. TPP Lippendorf and Schwarze Pumpe have changed each other in the top ten or appeared jointly in different years taking lower lines close to the threshold. TPP Frimmersdorf has left the top ten in 2012 due to its gradual shut down. Analysing the dynamics of verified emissions for these installations it should be noted, that they are relatively stable over time. Along with TPP Frimmesdorf the exemption is TPP Neurath with the rise in its emissions due to commissioning of two new 1060 MW units in 2012 (Figure 8).

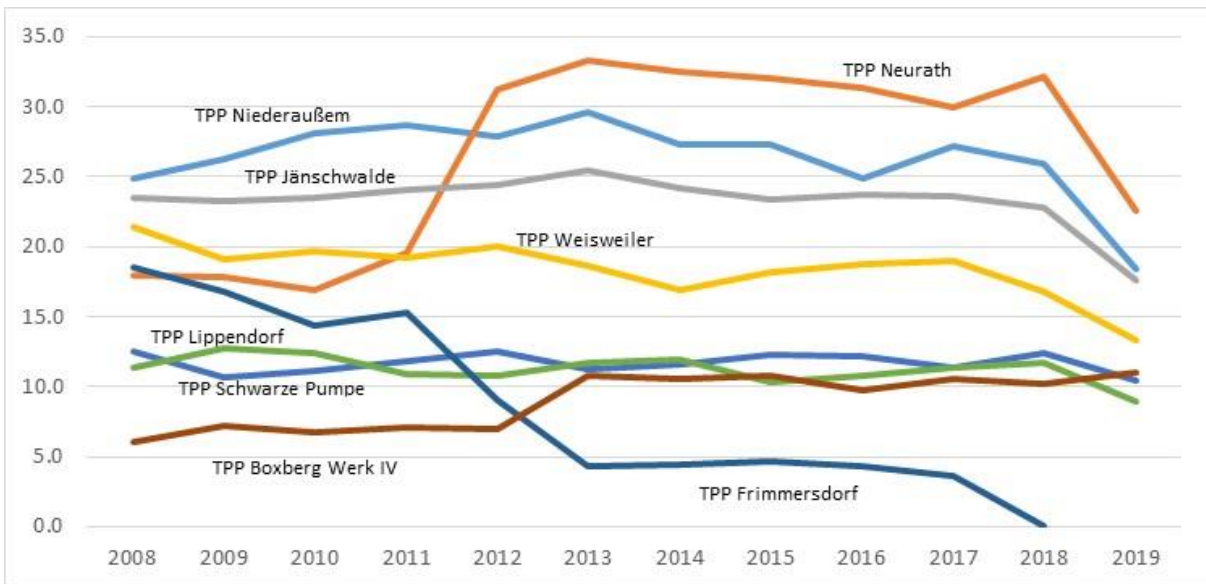

Figure 8. German TPP's verified emissions 2008-2019, mln t $\mathrm{CO}_{2}$.

Hard coal and lignite have long dominated power generation in Germany. In 2008, their share in power generation amounted 42.9\% (19.4\% hard coal and 23.5\% lignite) (AG Energiebilanzen 2020). Till 2018 Germany has made a remarkable progress in raising the share of renewables in generation mix up to $35 \%$, but at the same time the share of lignite remained almost stable at $22.6 \%$ with hard coal share decreased to $12.8 \%$. Physically the output of lignite power stations remained practically the same with $145 \mathrm{TWh}$ produced both in 2009 and 2018. Germany has long been criticized for the gap in its climate policy ambitions and little action on coal power stations (Keles \& Yilmaz 2020). Lack of necessary interconnections between new sites of renewable generation in the north of the country and southern industry centres along with nuclear power phase out have made the substitution of coal power in Germany particularly difficult (Zimakov 2018). While other leading EU countries were already pursuing coal phase-out, Germany has taken first cautious steps by gradually putting several units of four lignite power plants into security reserve since 2016 (Brauers et al. 2020). Nevertheless, this decision has not affected the top ten list. Only in 2019, Germany has committed to a coal phase out in power generation by 2038 - the most remote officially adopted exit date in the EU (Oei 2020).

Since 2016, unit IV of TPP Boxberg has joined the top ten. However, its emissions are almost stable around $10.8 \mathrm{mln} \mathrm{CO}_{2}$ since 2013. This case is similar to TPP Kozienice and should be explained by the overall reduction in verified emissions of power stations in other EU countries. 


\subsection{Upward trend for aviation}

The EU ETS includes the emissions from aviation sector since 2012. However, its scope is currently limited to emissions from flights within the European Economic Area (EEA) - the EU Member States plus Iceland, Liechtenstein and Norway. Even within this reduced scope the amount of emissions from aviation activity covered by the EU ETS is gradually rising. Based on EU ETS data the total verified emissions from aviation (activity code 10) have risen by 26.6\% since 2013 until 2019 (Figure 9). Meanwhile other industries included into EU ETS have shown a downward trend. For example, the emissions from power generation (activity code 20 ) have fallen by $29.3 \%$ in the same timeframe.

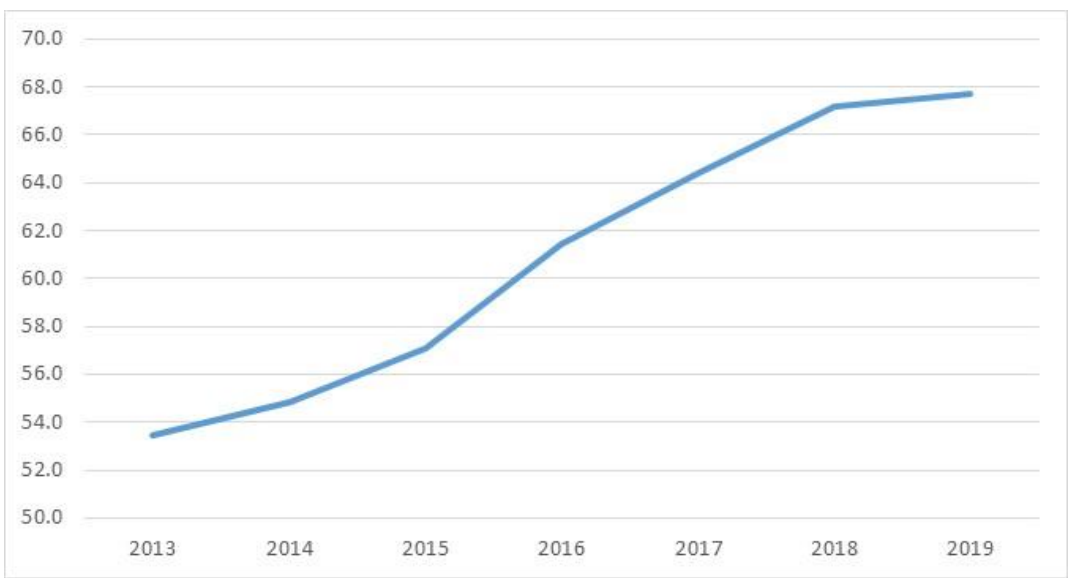

Figure 9. Aviation verified emissions 2013-2019, $m \ln +\mathrm{CO}_{2}$.

The upward trend for aviation activity related emissions is largely explained by the sharp rise in air traffic (Andrejiová et al. 2020). The decarbonisation of the transportation sector in the EU is notably lagging, especially compared to RES penetration in the power generation and heating/cooling: 8\% in 2018 against 32.1\% and 19.7\% for EU28 (Eurostat 2020). At the same time, the EU climate policy towards aviation sector is often criticized for its shortfalls to curb emissions (Efthymiou \& Papatheodorou 2019), which account for about 3\% of the EU's GHG total. The EU ETS cap for the aviation sector is calculated based on more relaxed norms compared to other industries. This will partially change in the $4^{\text {th }}$ phase of EU ETS (2021-2030). In addition to that, the EC intends to implement the CORSIA carbon-offsetting scheme for international flights from 2021 (Maertens $e t$ al. 2019).

Meanwhile, following the upward trend for aviation activity related emissions one aircraft operator - Ryanair DAC has joined the EU ETS top ten since 2018 (Figure 10).

Figure 10. Ryanair DAC ranking in EU ETS top ten.

\begin{tabular}{|c|cc|}
\hline Rank & 2018 & 2019 \\
\hline 8 & & \\
9 & Ryanair DAC & Ryanair DAC \\
10 & & \\
\hline
\end{tabular}




\section{Discussion}

The results support a correlation between the presence of national enterprises in the EU ETS top ten list and the national climate policy actions. This interdependence is more obvious in a year-on-year analysis that allows to trace certain trends driven by national climate policy (in)action. Therefore, the EU ETS top ten list as a performance indicator can provide evidence on (in)efficiency of national climate policy measures. Its accuracy however depends on certain parameters that can limit its functionality.

\subsection{Limitations of the EU ETS top ten list}

The general limitation of the top ten list rests with the scope of the EU ETS. Energy-intensive installations not covered by the system are virtually out of sight, thus can be overlooked by the climate action. For example, the emissions from the shipping sector are currently out of the EU ETS scope. At the same time, the shipping-related emissions are substantive. According to a study of International Maritime Organization (IMO), GHG emissions from shipping operations are expected to rise up to $50 \%$ by 2050 if no action taken (IMO 2020). Transport \& Environment NGO made calculations of a top ten EU ETS polluters list based on the assumption it includes emissions of the shipping associated with journeys to and from the EU (in similar fashion to the aviation). It shows that if the EU ETS would cover emissions of the shipping, the top polluters list in 2018 would include at least one company of the sector (Transport \& Environment 2019). In this case, the NGO based on the EU ETS top ten list correctly points out a climate policy shortcoming (Deane et al. 2019). It should be noted, that EC addresses this issue and extends the EU ETS to the maritime transport sector in June 2021 as part of Sustainable and Smart Mobility Strategy (European Commission 2020b).

Another limitation of the top ten polluters list is linked to the fact that it is carbon dioxide $\left(\mathrm{CO}_{2}\right)$ emissions-based. The EU ETS is specifically addressing main greenhouse gas as a cause of climate change. Actually, the EU ETS additionally covers also nitrous oxide (N2O) and perfluorocarbons (PFC) emissions, but its focus is nevertheless on CO2. That means the actual negative environmental impact caused by installations cannot be measured by EU ETS controlled emissions data only. For this purpose, the European Pollutant Release and Transfer Register (E-PRTR) data collected by the European Environment Agency (EEA) may be more suitable because of broader coverage of negative environmental impact factors. However, for a ranking approach of top ten it will require to calculate a number of ratings or a synthetic index, what makes the perception of the outcome by a broader audience more difficult. As a political tool, the EU ETS top ten effectively links carbon emissions to pollution what contributes to the ease of public perception.

Lack of data on verified emissions on certain installation can also affect the accuracy of the EU ETS top ten list. As mentioned earlier, the enterprises should provide the data by a certain deadline. If they miss it, the verified emissions data for the past year will appear later, and this installation will be out of the list calculation. This means, the outcome of the EU ETS top ten list calculations will be not fully correct. Such situations can be witnessed, for example, in 2019, where the verified emissions data of TPP Maritsa power station are missing, or in 2016 with no data on Bełchatów power station. The missing 
figures are added in later releases, however, that should be taken into account. To address this issue certain adjustments are sometimes done based on historical values or other sources. For example, Transport \& Environment NGO (Transport \& Environment, 2020b) uses 2018 verified emissions data for TPP Maritsa to adjust for missing data in 2019. However, this adjustment may be not fully correct considering the overall downward trend for coal power generation.

Another adjustment is sometimes applied by grouping several units. This stems from the fact, that EU ETS tracks the emissions from installations (or companies in aviation), not the facilities or company groups. Therefore, some facilities have several accounts registered separately. For example, the power station can have separate accounts for its units. This is explained by the fact that the units of those power stations usually function quite isolated and independent: some of them were built in different time; they can be located relatively remotely from each other and thus technically operating in a selfsustained manner, even if one management team manages them. However, some consider this split artificial and add up all the units to get a more realistic picture of the power station emissions. WWF when they add up accounts of Boxberg power station III and IV uses this approach (WWF 2007). A similar adjustment is applied to accounts of different companies belonging to one owner. A methodology applied by Transport \& Environment NGO is grouping accounts of airlines based on their ownership (Transport \& Environment 2020b). It should be nevertheless noted, that in both examples given the adjustments made no significant impact on top ten results and the adding up of the accounts was likely used to get more impressive emission figures for particular enterprises. It can be summarized, that the above limitations of the EU ETS top ten list are rather of methodological nature and can be addressed by introduction of a proper calculation methodology, which takes them duly into account. This again highlights the need in a single official EU ETS top ten calculation.

\subsection{Is ten a perfect number?}

Any top ten list is a tip of the broader ranking. Moreover, as any shortlist the EU ETS top ten suffers from the limitation to only 10 first lines what inevitably narrows the coverage. To avoid this limitation some papers are using a longer list. For example, WWF and CAN Europe are using a top 30 list (WWF 2007; CAN Europe et al. 2014). Such a long-list includes installations from more countries what is considered a major benefit. This can be substantial if the goal is to have a wider geographical scope or representation. At the same time, the broader scope means more diversity in the included industries what makes it harder to focus on specific trends. To address that WWF limits their top 30 to one industry (power generation) to demonstrate the environmental pollution caused by coal and lignite firing power stations and the urgent need of climate action. Actually, the same conclusion could be made based on the EU ETS top ten dominated by thermal power plants burning coal but that would limit the geographical representation. Some EU countries with high percentage of coal-based electricity would remain out of sight, for example, Czech Republic (Sivek et al. 2020).

A more condensed and focused short list can nevertheless be useful to raise awareness in those countries that host installations in the EU ETS top ten list. As mentioned in 3.2., German lignite power plants are long time leaders of the top ten. For several years, climate 
activists and the mass media many times highlighted this fact to prompt the German government to action (Der Spiegel 2014, 2017; Süddeutsche Zeitung 2015; Energie Zukunft 2019; Der Stern 2019).

Moreover, the rise of a new player to the top ten emitters list gives a strong signal, what can be seen when Ryanair DAC joined the EU ETS top ten in 2018. This fact was widely discussed in the media along with the overall upward trend for emissions from aviation activities (Transport \& Environment 2020b; BBC 2019). This trend would be less noticeable in a long list.

Passing of a top ten threshold is closely related to 'the top-ten effect' described by M. S. Isaac and R. M. Schindler (Isaac \& Schindler 2014). It shows that people give more value to improvements in rank that cross round-number-category boundaries. Another important consequence of this effect is the fact people more favourably evaluate shorter lists (Isaac et al. 2016).

The threshold of top ten represents a separate problem when some companies balance on verge and fall out of the top ten in one year, but make a comeback in the next year. This can be driven both by overall market fluctuations and by business activity of the installation. Nevertheless, the inability to leave the top ten completely indicates shortcomings in climate action. This can be said about Bulgaria's TPP Maritsa East 2 that joined the EU ETS top ten in 2011 (line 9) but left it in the next year to come back in 2015 (line 10). In 2016 it was out again (line 11) but back for one year in 2017 (line 10) just to return to line 11 in 2018. Analysing the fluctuations it can be noticed, that TPP Maritsa East 2 has joined the top ten list when there were spikes in its emissions and remained in top 20 for the rest of the time. However, the downward trend in coal power generation's emissions (Fig.7) has narrowed the gap between top ten and Maritsa power station, so that in recent years it more often became part of the top ten. Meanwhile the share of coal power generation in Bulgaria remains above $40 \%$ without any clear plans for a phase out (Mikalauskiene 2019).

The last example shows how an insight into longer top 20 list allows tracking of particular installation's emissions dynamics. It is a common wisdom that a broader scope delivers a bigger picture. This can be good for specific tasks, for instance, to determine future EU ETS developments: what industry will be the next "big polluter" after coal power generation finally gives up its positions. The top 20 can give such a hint towards steel industry. It can also give projections of the EU ETS top ten possible development: Ryanair DAC has entered the top 20 two years earlier, before it joined the EU ETS top ten. However, a shorter top ten list is sufficient and more suitable to provide focused highlights of climate policy (under)performance.

\subsection{EU ETS top ten as a "soft" tool to foster clean energy transition}

The examples given in 4.1. and 4.2. demonstrate, how climate action organizations like WWF, CAN Europe, Transportation\&Environment and other NGOs apply the EU ETS top polluters list as a policy tool to support their publicity campaigns, to track progress of clean energy transition or to raise awareness on problems or underperformance in combating climate change in the EU. Their findings are usually well perceived and widely reiterated by the European mass media thus reinforcing political pressure on underperforming governments and industries. 
A weak point of this tool, however, is the lack of a single 'official' EU ETS top polluters list. In its absence, the climate action organisations calculate their own ratings applying different methodologies, so there is a number of top EU polluters' shortlists, each of them referring to EU ETS. This weakens the political power of the tool as it may be challenged for different methodological approaches or bias.

Meanwhile, the EU ETS top ten list is a very appealing instrument with good visualization and easy perception. As there is a correlation between the EU ETS top ten and the performance of national climate policies, the list as a "soft" tool can be instrumental in promoting decarbonisation in the EU as a useful extension of the current policy framework (European Commission 2017). The potential efficiency of this tool in fostering clean transition may be moderate, but bearing in mind that it comes as a by-product at no cost, there is no obvious reason for the European Commission to refrain from making use of it. Unlikely to be wholly effective on its own, it will be nonetheless important to complement other instruments.

The EC could release an EU ETS top ten polluters list once a year along with publication of verified emissions data or a certain time later to incorporate adjustments due to late submissions of data as described in methodology section. Even without any dedicated press release or commentary by the EC, it would provide climate action organizations with a single official rating calculated according to a certain methodology. This official rating would then be a common reference point for environmental NGOs and other climate policy actors to make their own evaluation, commentary and to undertake further political actions fostering clean energy transition in the EU.

\section{Conclusions}

Recent research on EU climate policy suggests that there is a need in a mix of measures rather than relying on single tools like the EU ETS (Lindberg et al. 2019). In the variety of hard and soft EU climate policy instruments, there is also option for smaller tools like information and education what also includes different publicity campaigns and the introduction of rating systems. The EU ETS top ten polluters list could feature in the EU climate policy toolbox as an information tool, reflecting general trends in the national and EU-wide climate policy performance. It is especially important for climate action organizations, because it would provide them with an officially released rating that they could use in their evaluations and political campaigns. An official status of the EU ETS top ten could boost the political power of this tool and provide different actors with a common reference point.

Despite having limited geographical representation and covering only one aspect of sustainable development (curbing of $\mathrm{CO}_{2}$ emissions) the EU ETS top ten list as a tool has its own advantages. It focuses both on levels and on changes: it provides a focused information on top polluters and, based on year on year analysis, on respective changes driven by climate policy (under)performance in relevant EU countries or industries. Bearing limitations of a short list, the EU ETS top ten nevertheless adequately reflects main developments in national efforts to curb GHG emissions and is especially effective in pointing out underperforming countries and industries covered by the EU ETS. The envisaged extension of the EU ETS scope to other industries will make the top ten list 
even more informative. Finally, it comes almost at no cost compared to calculations of comprehensive sustainable development indexes or synthetic indicators.

\section{References}

AG Energiebilanzen (2020). Bruttostromerzeugung in Deutschland nach Energieträger. https://agenergiebilanzen.de/4-0-Arbeitsgemeinschaft.html

Andrejiová, M., Grincova, A., \& Marasová, D. (2020). Study of the Percentage of Greenhouse Gas Emissions from Aviation in the EU-27 Countries by Applying Multiple-Criteria Statistical Methods. Int. J. Environ. Res. Public Health, 17, 3759. https://doi.org/10.3390/ijerph17113759

Arrow, K. (1959). Rational Choice Functions and Orderings. Economica, New Series, Vol. 26, No. 102, 121 127. http://www.jstor.org/stable/2550390

BBC (2019). Ryanair one of Europe's top polluters, EU data suggests. BBC, 2 April 2019. https://www.bbc.com/news/business-47783992

Brauers, H., Oei, P.-Y., \& Walk, P. (2020). Comparing coal phase-out pathways: The United Kingdom's and Germany's diverging transitions. Environmental Innovation and Societal Transitions, 37, 238-253. https://doi.org/10.1016/j.eist.2020.09.001

Bernauer, T. (2013). Climate change politics. Annual Review of Political Science, 16, 421-448. https://doi.org/10.1146/annurev-polisci-062011-154926

CAN Europe, HEAL, WWF, EEB, \& Klima Allianz (2014). Europe's Dirty 30. Germany, July 2014. http://awsassets.panda.org/downloads/dirty_30_report_finale.pdf

CCC (2018). Biomass in a low-carbon economy. Committee on Climate Change, November 2018. https://www.theccc.org.uk/publication/biomass-in-a-low-carbon-economy/

Davies, E., Gift, T., \& Lastra-Anadon, C. X. (2020). How global performance assessments shape attitudes toward government decision-making: Survey experimental evidence [Article; Early Access]. Governance-an International Journal of Policy Administration and Institutions, 21. https://doi.org/10.1111/gove.12504

Deane, F., Huggins, A., \& Karim, M. S. (2019). Measuring, monitoring, reporting and verification of shipping emissions: Evaluating transparency and answerability. Review of European, Comparative and International Environmental Law, 28(3), 258-267. https://doi.org/10.1111/reel.12308

Derman, B. B. (2014). Climate governance, justice, and transnational civil society. Climate Policy, 14(1), 23-41. https://doi.org/10.1080/14693062.2014.849492

Der Spiegel (2014). Deutsche Kraftwerke sind die schmutzigsten in Europa Der Spiegel online, 02.04.2014. https://www.spiegel.de/wirtschaft/unternehmen/kohlekraftwerke-in-deutschland-stossen-mehrco2-aus-als-im-eu-schnitt-a-962028.html

Der Spiegel (2017). Deutschlands größte Klimasünder. Der Spiegel online, 16.11.2017 https://www.spiegel.de/wissenschaft/mensch/deutschland-das-sind-die-groessten-klimasuendera-1178207.html

Der Stern (2019). Deutschland stehen sieben der größten CO2-Verursacher Europas. Stern online, 02.04.2019 https://www.stern.de/panorama/wissen/in-deutschland-stehen-sieben-der-groessten-co2verursacher-europas-8648900.html

Dickel, R. (2018). The role of natural gas, renewables and energy efficiency in decarbonisation in Germany: The need to complement renewables by decarbonized gas to meet the Paris targets. Oxford Institute for Energy Studies. https://doi.org/10.26889/9781784671082

Doshi, R., Kelley, J. G., \& Simmons, B. A. (2019). The Power of Ranking: The Ease of Doing Business Indicator and Global Regulatory Behavior [Article]. International Organization, 73(3), 611-643, Article Pii s0020818319000158. https://doi.org/10.1017/s0020818319000158

Dutta, R., \& Horan, S. (2015). Inferring Rationales from Choice: Identification for Rational Shortlist Methods. American Economic Journal, Microeconomics, 7 (4), 179-201. https://doi.org/10.1257/mic.20130118

Efthymiou, M., \& Papatheodorou, A. (2019). EU Emissions Trading scheme in aviation: Policy analysis and suggestions. Journal of Cleaner Production, Volume 237, 117734. https://doi.org/10.1016/j.jclepro.2019.117734. 
Enel (2020). Early closure of the Brindisi thermal plant's Unit 2 authorized. Press release, 28 May 2020. https://www.enel.com/content/dam/enel-common/press/en/2020-May/Dismissione $\% 20$ centrale $\% 20$ Brindisi $\% 20$ ENG.pdf

Energie Zukunft (2019). Von den 10 größten Klimasündern kommen 7 aus Deutschland. Energie Zukunft, 05.04.2019. https://www.energiezukunft.eu/klimawandel/von-den-10-groessten-klimasuendernkommen-7-aus-deutschland/

EnEx (2020). Yearly DAS Trading System Report 2019. Energy Exchange Group. http://www.enexgroup.gr/fileadmin/groups/EDRETH/DAS_Yearly_Reports/2019_DAS_Year ly_Report_en.pdf

Euractiv (2020). Poland to accelerate coal phase-out, spend billions on renewable and nuclear energy. $\begin{array}{lllll}\text { EURACTIV.com with } & \text { Reuters } & \text { Sep } & 92\end{array}$ https://www.euractiv.com/section/energy/news/poland-to-accelerate-coal-phase-out-spendbillions-on-renewable-and-nuclear-energy/

European Commission (2017). Better regulation "Toolbox". Staff Working Document (SWD (2017) 350. https://ec.europa.eu/info/sites/info/files/better-regulation-toolbox_2.pdf

European Commission (2020a). Report on the functioning of the European carbon market. COM(2019) 557 final/2 Brussels, 16.1.2020. https://eur-lex.europa.eu/legal-content/EN/TXT/?uri=CELEX: 52019DC0557R $(01)$

European Commission (2020b). Sustainable and Smart Mobility Strategy - putting European transport on track for the future $\operatorname{COM}(2020) 789$ final, Brussels, 9.12 .2020 . https://ec.europa.eu/transport/sites/transport/ files/legislation/com20200789.pdf

Eurostat (2020). Shares of energy from renewable sources, summary results 2019. https://ec.europa.eu/eurostat/web/energy/data/shares

Fermeglia, M. (2020). Legal Pathways to Coal Phase-Out in Italy in 2025. Energies, 13(21), 5605. https://doi.org/10.3390/en13215605

Gasparotto, J., \& Da Boit Martinello, K. (2020). Coal as an energy source and its impacts on human health. Energy Geoscience, In Press, Corrected Proof, Available online 18 July 2020. https://doi.org/10.1016/j.engeos.2020.07.003

Geng, S., \& Özbay, E. Y. (2020). Shortlisting procedure with a limited capacity. Journal of Mathematical Economics, 102447, https://doi.org/10.1016/j.jmateco.2020.11.003

Grubb, M., Crawford-Brown, D., Neuhoff, K., Schanes, K., Hawkins, S., \& Poncia, A. (2020). Consumptionoriented policy instruments for fostering greenhouse gas mitigation. Climate Policy, 20:sup1, 58-73. https://doi.org/10.1080/14693062.2020.1730151

IMO (2020). Reduction of GHG emissions from ships. Fourth IMO GHG Study 2020 - Final report. https://docs.imo.org/Default.aspx

Isaac, M. S., Brough, A. R., \& Grayson, K. (2016). Is Top 10 Better than Top 9? The Role of Expectations in Consumer Response to Imprecise Rank Claims. Journal of Marketing Research, 53(3), 338-353. https://doi.org/10.1509/jmr.14.0379

Isaac, M. S., \& Schindler, R. M. (2014). The top-ten effect: Consumers' subjective categorization of ranked lists. Journal of Consumer Research, 40(6), 1181-1202. https://doi.org/10.1086/674546

Isoaho, K., \& Markard, J. (2020). The politics of technology decline: Discursive struggles over coal phase-out in the UK. Review of Policy Research, 37(3), 342-368. doi:10.1111/ropr.12370

Jasper, J. M. (2011). Emotions and social movements: Twenty years of theory and research. Annual Review of Sociology, 37, 285-303. https://doi.org/10.1146/annurev-soc-081309-150015

Keles, D., \& Yilmaz, H. Ü. (2020). Decarbonisation through coal phase-out in Germany and Europe — impact on emissions, electricity prices and power production. Energy Policy, 141. https://doi.org/10.1016/j.enpol.2020.111472

Lindberg, M. B., Markard, J., \& Andersen, A. D. (2019). Policies, actors and sustainability transition pathways: A study of the EU's energy policy mix. Research Policy, 48, 10, 103668. https://doi.org/10.1016/j.respol.2018.09.003

Lleras J. S., Masatlioglu Y., Nakajima D., \& Ozbay E.Y. (2017). When more is less: Limited consideration. Journal of Economy Theory, 170, 70-85. http://dx.doi.org/10.1016/j.jet.2017.04.004

Maertens, S., Grimme, W., Scheelhaase, J., \& Jung, M. (2019). Options to Continue the EU ETS for Aviation in a CORSIA-World. Sustainability, 11, 5703. https://doi.org/10.3390/su11205703 
Manzini, P, \& Mariotti, P. (2007). Sequentially Rationalizable Choice. American Economic Review, 97(5), 1824-1839.

Markard, J., \& Rosenbloom, D. (2020). Political conflict and climate policy: The European Emissions Trading System as a Trojan horse for the low-carbon transition? Climate Policy, 20(9), 1092-1111. https://doi.org/10.1080/14693062.2020.1763901

Mikalauskiene, A., Štreimikis, J., Mikalauskas, I., Stankūniene, G., \& Dapkus, R. (2019). Comparative assessment of climate change mitigation policies in fuel combustion sector of Lithuania and Bulgaria. Energies, 12(3), 529. https://doi.org/10.3390/en12030529

Miller, G. A. (1956). The magical number seven, plus or minus two: some limits on our capacity for processing information. Psychological Review, 63(2), 81-97. https://doi.org/10.1037/h0043158

National Energy and Climate Plan (NCEP) (2019). Ministry of the Environment and Energy, Hellenic Republic Athens, December 2019. https://ec.europa.eu/energy/sites/ener/files/el_final_necp_main_en.pdf

Oei, P.-Y., Hermann, H., Herpich, P., Holtemöller, O., Lünenbürger, \& B., Schult, C. (2020). Coal phase-out in Germany - implications and policies for affected regions. Energy, 196. https://doi.org/10.1016/j.energy.2020.117004

Olsen, A. L. (2015). The Numerical Psychology of Performance Information: Implications for Citizens, Managers, and Policymakers. Public Performance \& Management Review, 39(1), 100-115. https://doi.org/10.1080/15309576.2016.1071167

Qin, D. (2021). Exclusive shortlisting choice with reference. Economics Letters, 198, 109675. https://doi.org/10.1016/j.econlet.2020.109675

Ramsey, D. (2019). Optimal selection from a set of offers using a short list. Multiple Criteria Decision Making, 14, 75-92. https://doi.org/10.22367/mcdm.2019.14.05

Ramsey, D. (2020). A Game Theoretic Model of Choosing a Valuable Good via a Short List Heuristic. Mathematics, 8, 199. https://doi.org/10.3390/math8020199

Rentier, G., Lelieveldt, H., \& Kramer, G., J. (2019). Varieties of coal-fired power phase-out across Europe. Energy Policy, 132, 620-632. doi:10.1016/j.enpol.2019.05.042

Salgado, R. S. (2018). The advocacy of feelings: Emotions in EU-based civil society organizations' strategies. Politics and Governance, 6(4), 103-114. doi:10.17645/pag.v6i4.1505 Simon, H. A. (1956) Rational choice and the structure of the environment. Psychol. Rev., 63, 129.

Sivek, M., Jirásek, J., Kavina, P., Vojnarová, M., Kurková, T. \& Bašová, A. (2020). Divorce after hundreds of years of marriage: Prospects for coal mining in the Czech Republic with regard to the European Union. Energy Policy, vol. 142, 111524. https://doi.org/10.1016/j.enpol.2020.111524

Süddeutsche Zeitung (2015). Europas schmutzigste Kraftwerke stehen in Deutschland. Süddeutsche Zeitung, 1. April 2015. https://www.sueddeutsche.de/wirtschaft/co2-emission-europas-klimaschaedlichstekraftwerke-stehen-in-deutschland-1.2420130

The Guardian (2020). Fight the power: why climate activists are suing Europe's biggest coal plant. The Guardian, 26 Sep 2019. https://www.theguardian.com/environment/2019/sep/26/fight-powerclimate-activists-europe-biggest-coal-poland-bechatow

Transport \& Environment (2019). EU shipping's climate record. European Federation for Transport and Environment AISBL. https://www.transportenvironment.org/sites/te/files/publications/StudyEU_shippings_climate_record_20191209_final.pdf

Transport \& Environment (2020a). EU ETS Registry data analysis. Methodology note. April 2020. https://www.transportenvironment.org/sites/te/files/2020_04_TE_ETS_data_treatment.pdf

Transport \& Environment (2020b). Ryanair Europe's 7th biggest carbon polluter last year as aviation emissions continued to grow. Transport \& Environment. April 16, 2020. https://www.transportenvironment.org /press/ryanair-europe's-7th-biggest-carbon-polluter-last-year-aviation-emissions-continued-grow

Verbruggen, A., Laes, E., \& Woerdman, E. (2019). Anatomy of Emissions Trading Systems: What is the EU ETS? Environmental Science \& Policy, 98, 11-19. https://doi.org/10.1016/j.envsci.2019.05.001

Vlassopoulos, C. (2020). Persistent lignite dependency: The Greek energy sector under pressure. Energy Policy, Volume 147, 111825. https://doi.org/10.1016/j.enpol.2020.111825.

WWF (2007). Dirty Thirty. Ranking of the most polluting power stations in Europe. https://wwfeu.awsassets.panda.org/downloads/european_dirty_thirty_may_2007.pdf

Zimakov, A. (2017). Is There Any Future for Coal Power Plants in Europe? MGIMO Review of International Relations, 5 (56), 130-150. https://doi.org/10.24833/2071-8160-2017-5-56-130-150 
Zimakov, A. (2018). Energy infrastructure transformation as part of clean energy transition in the EU. World Economy and International Relations, vol. 62, no. 12, pp. 46-54. https://doi.org/10.20542/01312227-2018-62-12-46-54

Zhao, N., \& You, F. (2020). Can renewable generation, energy storage and energy efficient technologies enable carbon neutral energy transition? Applied Energy, 279, 115889. https://doi.org/10.1016/i.apenergy.2020.115889

\section{Appendix A}

EU ETS top ten lists by year for the period 2008-2019, $\mathrm{mln} \mathrm{t} \mathrm{CO}_{2}$.

\begin{tabular}{|c|c|c|c|c|c|c|}
\hline & 2008 & & 2009 & & 2010 & \\
\hline Rank & Installation & $\mathrm{CO}_{2}$ & Installation & $\mathrm{CO}_{2}$ & Installation & $\mathrm{CO}_{2}$ \\
\hline 1 & TPP Bełchatów (PL) & 30.9 & TPP Bełchatów (PL) & 29.5 & TPP Bełchatów (PL) & 29.7 \\
\hline 2 & TPP Niederaußem (DE) & 24.9 & TPP Niederaußem (DE) & 26.3 & TPP Niederaußem (DE) & 28.1 \\
\hline 3 & TPP Jänschwalde (DE) & 23.5 & TPP Jänschwalde (DE) & 23.3 & TPP Jänschwalde (DE) & 23.5 \\
\hline 4 & Drax Power Station (UK) & 22.3 & Drax Power Station (UK) & 19.9 & Drax Power Station (UK) & 22.4 \\
\hline 5 & TPP Weisweiler (DE) & 21.4 & TPP Weisweiler (DE) & 19.0 & TPP Weisweiler (DE) & 19.7 \\
\hline 6 & TPP Frimmersdorf (DE) & 18.6 & TPP Neurath (DE) & 17.9 & TPP Neurath (DE) & 16.9 \\
\hline 7 & TPP Neurath (DE) & 18.0 & TPP Frimmersdorf (DE) & 16.8 & TPP Frimmersdorf (DE) & 14.3 \\
\hline 8 & TPP Brindisi Sud (IT) & 14.9 & TPP Brindisi Sud (IT) & 13.0 & TPP Agios Dimitrios (GR) & 14.3 \\
\hline 9 & TPP Turów (PL) & 12.9 & TPP Agios Dimitrios (GR) & 12.9 & TPP Lippendorf (DE) & 12.5 \\
\hline \multirow[t]{2}{*}{10} & TPP Schwarze Pumpe (DE) & 12.5 & TPP Lippendorf (DE) & 12.8 & TPP Schwarze Pumpe (DE) & 11.1 \\
\hline & 2011 & & 2012 & & 2013 & \\
\hline Rank & Installation & $\mathrm{CO} 2$ & Installation & $\mathrm{CO} 2$ & Installation & $\mathrm{CO} 2$ \\
\hline 1 & TPP Bełchatów (PL) & 32.8 & TPP Bełchatów (PL) & 35.2 & TPP Bełchatów (PL) & 37.2 \\
\hline 2 & TPP Niederaußem (DE) & 28.6 & TPP Neurath (DE) & 31.2 & TPP Neurath (DE) & 33.3 \\
\hline 3 & TPP Jänschwalde (DE) & 24.0 & TPP Niederaußem (DE) & 27.9 & TPP Niederaußem (DE) & 29.6 \\
\hline 4 & Drax Power Station (UK) & 21.5 & TPP Jänschwalde (DE) & 24.4 & TPP Jänschwalde (DE) & 25.4 \\
\hline 5 & TPP Neurath (DE) & 19.6 & Drax Power Station (UK) & 22.7 & Drax Power Station (UK) & 20.3 \\
\hline 6 & TPP Weisweiler (DE) & 19.2 & TPP Weisweiler (DE) & 20.0 & TPP Weisweiler (DE) & 18.7 \\
\hline 7 & TPP Frimmersdorf (DE) & 15.2 & TPP Agios Dir & 14.7 & TPP Agios Di & 13.1 \\
\hline 8 & TPP Agios Dimitrios (GR) & 14.2 & TPP Schwarze Pumpe (DE) & 12.5 & TPP Brindisi Sud (IT) & 11.8 \\
\hline 9 & TPP Maritsa East 2 (BG) & 13.0 & TPP Brindisi Sud (IT) & 12.2 & TPP Lippendorf (DE) & 11.7 \\
\hline \multirow[t]{2}{*}{10} & TPP Schwarze Pumpe (DE) & 11.9 & ArcelorMittal Atlantique (FR) & 11.2 & Eggborough TPP (UK) & 11.5 \\
\hline & 2014 & & 2015 & & 2016 & \\
\hline Rank & Installation & $\mathrm{CO} 2$ & Installation & $\mathrm{CO} 2$ & Installation & $\mathrm{CO} 2$ \\
\hline 1 & TPP Bełchatów (PL) & 36.9 & TPP Bełchatów (PL) & 37.1 & TPP Bełchatów (PL) & 34.9 \\
\hline 2 & TPP Neurath (DE) & 32.4 & TPP Neurath (DE) & 32.1 & TPP Neurath (DE) & 31.3 \\
\hline 3 & TPP Niederaußem (DE) & 27.2 & TPP Niederaußem (DE) & 27.3 & TPP Niederaußem (DE) & 24.8 \\
\hline 4 & TPP Jänschwalde (DE) & 24.2 & TPP Jänschw & 23.3 & TPP Jänschwal & 23.8 \\
\hline 5 & TPP Weisweile & 16.9 & TPP Weiswe & 18.1 & TPP Weisweiler (DE) & 18.7 \\
\hline 6 & Drax Power Station (UK) & 16.6 & Drax Power Station (UK) & 13.2 & TPP Schwarze Pumpe (DE) & 12.2 \\
\hline 7 & TPP Brindisi Sud (IT) & 12.0 & TPP Brindisi Sud (IT) & 13.1 & TPP Kozienice (PL) & 12.0 \\
\hline 8 & TPP Lippendorf (DE) & 11.9 & TPP Schwarze Pumpe (DE) & 12.2 & TPP Lippendorf (DE) & 10.8 \\
\hline 9 & TPP Agios Dimitrios (GR) & 11.8 & TPP Kozienice (PL) & 11.4 & TPP Torrevaldaliga Nord (IT) & 10.2 \\
\hline \multirow[t]{2}{*}{10} & TPP Schwarze Pumpe (DE) & 11.6 & TPP Maritsa East 2 (BG) & 11.3 & TPP Boxberg Werk IV (DE) & 9.7 \\
\hline & 2017 & & 2018 & & 2019 & \\
\hline Rank & Installation & $\mathrm{CO} 2$ & Installation & $\mathrm{CO} 2$ & Installation & $\mathrm{CO} 2$ \\
\hline 1 & TPP Bełchatów (PL) & 37.6 & TPP Bełchatów (PL) & 38.3 & TPP Bełchatów (PL) & 32.7 \\
\hline 2 & TPP Neurath (DE) & 29.9 & TPP Neurath (DE) & 32.2 & TPP Neurath (DE) & 22.6 \\
\hline 3 & TPP Niederaußem (DE) & 27.2 & TPP Niederaußem (DE) & 25.9 & TPP Niederaußem (DE) & 18.4 \\
\hline 4 & TPP Jänschwalde (DE) & 23.6 & TPP Jänschwalde (DE) & 22.8 & TPP Jänschwalde (DE) & 17.6 \\
\hline 5 & TPP Weisweiler (DE) & 18.9 & TPP Weisweiler (DE) & 16.8 & TPP Weisweiler (DE) & 13.3 \\
\hline 6 & TPP Schwarze Pumpe (DE) & 11.4 & TPP Schwarze Pumpe (DE) & 12.4 & TPP Boxberg Werk IV (DE) & 11.0 \\
\hline 7 & TPP Lippendorf (DE) & 11.4 & TPP Lippendorf (DE) & 11.7 & TPP Schwarze Pumpe (DE) & 10.5 \\
\hline 8 & TPP Kozienice (PL) & 11.2 & TPP Boxberg Werk IV (DE) & 10.2 & TPP Kozienice (PL) & 10.5 \\
\hline 9 & TPP Boxberg Werk IV (DE) & 10.6 & Ryanair DAC (IR) & 9.9 & Ryanair DAC (IR) & 10.5 \\
\hline 10 & TPP Maritsa East 2 (BG) & 10.5 & TPP Kozienice (PL) & 9.7 & TPP Lippendorf (DE) & 8.9 \\
\hline
\end{tabular}

